\title{
Employment Absorption: Elasticity in the Industry and Services Sector in Indonesia
}

\author{
Dio Caisar DARMA ${ }^{1}$ \\ Jati KASUMA2 \\ Muhammad IKBAL 3
}

\begin{abstract}
Increased economic development in the industrial and service sectors is a component that is expected to be able to contribute significantly to the Indonesian economy. The research objective is to compare the number of absorbed workforces and employment elasticity in the industrial and service sectors in Indonesia. Variables used in this study consist of the variable influence of labor and GDP on production units, in this case, the industrial sector and the service sector which can later compare elasticities employment opportunities in the industrial and service sectors. In this study, the type of data used is secondary data from 2010-2019. The analytical tool used is a two-step structural model and analyzed using SPSS. From the results of the analysis, it was found that the elasticity of employment in the industrial sector is positive inelastic. The elasticity of employment in the service sector is positive inelastic. The elasticity of employment in the service sector is greater than the elasticity of employment in the industrial sector in Indonesia.
\end{abstract}

KEYWORDS: economic growth, employment, GDP, industrial sector, service sector.

JEL CLASSIFICATION: E24, O10, L7, L89

\section{INTRODUCTION}

Developing countries that have limited resources generally focus on developing policies to boost investment levels (Porter \& Kramer 2019). Although the value of an investment is important to spur economic growth and employment, the amount is limited, and there must be an achievement of sustainable investment and increased productivity for balanced economic development (Ahluwalia, 1991).

The process of acquiring and increasing the number of people who have the expertise, education, and experience is decisive for a country's economic and political development. Human capital formation is therefore associated with an investment in humans and its development as a creative and productive source (Jhingan, 1993). However, for conceptual clarity, there should be a distinction between economic development and development in a broader sense encompassing non-economic values and goals, and these additional development goals are more appropriately included in the latter (Lee, 2017). This section discusses the three essential components of economic development; i.e: growth, distribution, and innovation.

\footnotetext{
${ }^{1}$ Sekolah Tinggi Ilmu Ekonomi Samarinda, Department of Management, Indonesia, diocaisar09@gmail.com

${ }^{2}$ University Teknologi MARA Malaysia (Sarawak Campus), Faculty of Business Management, Malaysia, jati@uitm.edu

3 Mulawarman University, Faculty of Economics and Business, Department of Accounting, Indonesia, muhammad.ikbal@feb.unmul.ac.id
} 
In the current era of globalization, the agricultural sector which is a traditional sector is slowly moving towards the manufacturing industry sector that uses and implements sophisticated technology and large capital but only uses little labor. While the service sector is slowly beginning to sink due to the lack of the role of investors in developing the service sector, so that with the increasing role of the industrial and service sectors being strong it is expected to spur national and regional economies, especially in absorbing labor and opening as many new jobs as possible, so that the impact immediately reduce the unemployment rate.

Some problems in the Indonesian economy, such as employment have become the main headline. This stems from population growth and an unbalanced level of employment. Also, the main triggering factors are the requirements applied by the industrial and service sectors inversely proportional to the lack of skills of the workforce. If they are well trained, it can help the production process (goods and services), otherwise, it will be an economic burden (Putri, 2012).

Efforts to improve people's welfare include several factors and aspects such as economic, social, political, and cultural. Almost all regions in Indonesia have the same problem, namely in the employment sector where in this sector it cannot yet accommodate a large number of workers due to lack of opportunities to work.

In addition, to create a high level of employment, in this case, there must be an increase in production in economic activity. This can be done by creating investment because an investment is the first step in production activities. Based on the background description, phenomena, and previous research references, the objectives to be achieved by the authors in the study are: (1) Knowing the amount of labor absorbed in the industrial and service sectors in Indonesia; (2) Knowing the elasticity of employment opportunities in the industrial and service sectors in Indonesia; and (3) Comparing the effect of employment opportunities on the industrial and service sectors in Indonesia.

\section{EXISTING THEORY}

Increased economic development in the industrial and service sectors is a component that is expected to be able to contribute significantly to development in a broad sense, carried out in a planned and gradual manner, so that the industrial and service sectors in the structure of the Indonesian economy can increase national income as a whole and per capita. The term industry can be defined as a collection of similar companies. With this understanding, all sectors of the economy can be said to be a separate industry, for example, the consumer goods industry, the small equipment industry, the agricultural industry, or the service industry. Thus, industrialization is defined as the construction of manufacturing companies that produce goods which are generally referred to as industrial goods, in a sector known as the modern economic sector.

Growth in the productivity of the lagging workforce (such as services) can reduce the value of work. However, the addition of value in the income elasticity through demand will always increase the proportion of work, because it can strengthen relative competitiveness and increase labor productivity in the service sector. This can increase market share and the proportion of jobs. Several factors in terms of improving employment proportions are not due to lagging productivity growth, but rather due to an increase in the effect of income demand. As a result, the high wage of labor is directly proportional to the improvement of the service itself (Liang \& Zhang, 2013).

Workers classified as productive (aged 15-64 years) are divided into the labor force and nonlabor force. Workers are people who have jobs in various economic sectors, while nonworkers are those who work at productive age, but do not have work for several reasons, such 
as going to school to study and as a full-time housewife taking care of his family (Autor \& Duggan, 2003; Mosisa \& Hipple, 2006; Chinhui \& Potter, 2006; Lee \& Mather, 2008).

Industrialization or industrial development is expected to be able to create jobs and have a dual effect on expanding employment opportunities. Industrialization is a motor of economic development and is expected to overcome the problem of employment opportunities (Rahardjo, 1986). Meanwhile, one of the arguments for industrialization is the creation of employment opportunities and is suitable for developing countries that have large populations (Dumairy, 1996).

However, there are weaknesses if the industries that are built do not have strong links either forward or backward or cannot play a role as a leading sector. The that industrial growth will not provide lasting benefits if it does not have a strong multiplier effect (income and employment opportunity) or direct, or indirect linkages with other sectors because the industry will grow on its own with a foundation fragile ones (Suseno, 2001).

\section{METHODOLOGY}

Based on the problem, objectives and theoretical framework as well as the concepts and hypotheses and analytical tools used, this research uses an associative quantitative approach. In this study included in the type of social research that explains the causality of variables through testing the hypothesis of employment elasticity in the industrial sector in Indonesia.

The scope of this research is limited to the number of workers, job opportunities and GDP values in the industrial and service sectors in Indonesia for a period of 10 years, where for this purpose the author deals directly with several offices or agencies involved in writing this is the BPS-Statistics of Indonesia.

The data that has been collected is then systematically analyzed for testing hypotheses and for finding certain economic measures (Intriligator, 1980). The model used is the Geometric Function or Cobb Douglas one variable with the Dummy variable as follows:

$$
\mathrm{N}=\mathrm{AQ}^{\alpha_{1}} \mathrm{e}^{\alpha_{2 \mathrm{D}}+\alpha_{3} \mathrm{DLn} \mathrm{Q}}
$$

Where: $N$ is the Absorption of Industrial and Service Workers, $Q$ is a Gross Domestic Product (GDP), $A$ is a Constant Number, $e$ is Natural Logarithm, $\alpha_{1} \alpha_{2} \alpha_{3}$ is Parameters to be Determined, $D$ is Dummy Variable, ( $D=0$ is Industrial Sector; $D=1$ is Service Sector).

The above function or equation (1) is written in linear form, so the following equation is obtained:

$\operatorname{Ln} N=\operatorname{Ln} A+\alpha_{1} \operatorname{Ln} Q+\alpha_{2} D+\alpha_{3} D \operatorname{Ln} Q$

If the values of the Dummy variable $(D)$ are included in equation (2) above, we get of the Industrial Sector: $D=0$; Function:

$\mathrm{N}=\mathrm{AQ}^{\alpha}{ }^{\alpha}$

Or in linear form obtained:

$\operatorname{Ln} \mathrm{N}=\operatorname{Ln} \mathrm{A}+\alpha_{1} \operatorname{Ln} \mathrm{Q}$

Service Sector: D = 1; Function:

$$
\mathrm{N}=\mathrm{e}^{\operatorname{Ln} A+\alpha_{2}} \mathrm{Q}^{\alpha_{1}+\alpha_{3}}
$$


Or in linear form obtained:

$\operatorname{Ln} N=\left(\operatorname{Ln} A+\alpha_{2}\right)+\left(\alpha_{1}+\alpha_{3}\right) \operatorname{Ln} Q$

To determine the coefficients of $\operatorname{Ln} \mathrm{A}, \alpha_{1}, \alpha_{2}, \alpha_{3}$ in equation (2), the following example is used:

$\operatorname{Ln} \mathrm{N}=\mathrm{Y}$

$\operatorname{LnA}=\mathrm{A}_{0}$

$\operatorname{Ln} \mathrm{Q}=\mathrm{X}_{1}$

$\mathrm{D}=\mathrm{X}_{2}$

$\mathrm{D} \operatorname{Ln} \mathrm{Q}=\mathrm{X}_{3}$

Thus, obtained the Multiple Linear Regression equation as follows:

$Y=A_{0}+\alpha_{1} X_{1}+\alpha_{2} X_{2}+\alpha_{3} X_{3}$

\section{RESULTS OF RESEARCH}

Based on the data obtained regarding employment elasticity in the industrial and service sectors in Indonesia within ten years in the period 2010-2019, an analysis of the data obtained will be carried out. The data will be processed as follows:

Table 1. Data on labor absorption and GDP in the industrial and service sectors in Indonesia, 2010-2019

\begin{tabular}{|c|c|c|c|c|}
\hline \multirow{2}{*}{ Year } & \multicolumn{2}{|c|}{ Manpower Absorption (People) } & \multicolumn{2}{c|}{ GDP (IDR Million) } \\
\cline { 2 - 5 } & Industrial Sector & Service Sector & Industrial Sector & Service Sector \\
\hline 2010 & $156,681,000$ & $502,791,000$ & $80,150,778,000$ & $31,722,604,000$ \\
\hline 2011 & $160,777,000$ & $553,721,000$ & $111,428,787,000$ & $42,367,650,000$ \\
\hline 2012 & $164,692,000$ & $604,651,000$ & $83,785,454,000$ & $48,796,010,000$ \\
\hline 2013 & $177,852,000$ & $731,747,000$ & $122,581,779,000$ & $48,382,559,000$ \\
\hline 2014 & $176,944,000$ & $797,161,000$ & $123,083,781,000$ & $56,857,047,000$ \\
\hline 2015 & $207,893,000$ & $790,250,000$ & $124,253,706,000$ & $64,126,573,000$ \\
\hline 2016 & $210,794,000$ & $816,972,000$ & $132,339,977,000$ & $70,805,172,000$ \\
\hline 2017 & $207,667,000$ & $828,416,000$ & $146,218,567,000$ & $79,465,092,000$ \\
\hline 2018 & $190,029,000$ & $778,167,000$ & $151,087,769,000$ & $87,590,054,000$ \\
\hline 2019 & $195,298,000$ & $910,305,000$ & $152,629,991,000$ & $94,857,233,000$ \\
\hline
\end{tabular}

Table 2 shows the Correlation Coefficient (R) of 0.994. This shows that there is a very strong relationship between the dependent variable (industrial and service sector workers) and the independent variable (GDP and dummy). The coefficient of determination obtained is 0.989 . This shows that the variation of the independent variable changes can explain the variation of the dependent variable changes of $98.9 \%$. This model is feasible because the variety of changes in other independent variables that explain variations in changes in the dependent variable that is not calculated is only $1.1 \%$. 
Table 2. Result of calculation of determination coefficient

\begin{tabular}{|c|c|c|c|c|}
\hline Model & R & R Square & $\begin{array}{c}\text { Adjusted R } \\
\text { Square }\end{array}$ & $\begin{array}{c}\text { Std. Error } \\
\text { of the Estimate }\end{array}$ \\
\hline 1 & $.994^{\mathrm{a}}$ & .989 & .987 & .08216 \\
\hline
\end{tabular}

Table 3 shows the results of the simultaneous hypothesis test based on probability (significance). The hypotheses used are:

$\mathrm{H}_{0}=0$; there is no simultaneous influence of independent variables on the dependent variable. $\mathrm{H}_{1} \neq 0$; there is the effect of independent variables simultaneously on the dependent variable.

Based on the results of the analysis, the calculated $F$ value was 477.206 and the significance value was 0.000 . Because the $\mathrm{F}$ count is greater than the $\mathrm{F}$ table that is 477.206 is greater than 4.76 and the significance value is smaller than alpha which is 0.000 less than 0.05 , then $\mathrm{H}_{0}$ is rejected and $\mathrm{H}_{1}$ is accepted. This shows that the independent variables (GDP and dummy) simultaneously influence the dependent variable (employment of industrial and service sectors).

Table 3. F test calculation results on ANOVA

\begin{tabular}{|c|l|r|r|r|r|c|}
\hline \multicolumn{2}{|c|}{ Model } & $\begin{array}{c}\text { Sum } \\
\text { of Squares }\end{array}$ & df & Mean Square & F & Sig. \\
\hline \multirow{2}{*}{1} & Regression & 9.663 & 3 & 3.221 & 477.206 & $.000^{\mathrm{b}}$ \\
\cline { 2 - 7 } & Residual & .108 & 16 & .007 & & \\
\cline { 2 - 7 } & Total & 9.771 & 19 & & & \\
\hline \multicolumn{7}{|c|}{ Source: Author(s) calculation } \\
\end{tabular}

A constant value of 5.009 is obtained. GDP regression coefficient (X1) of 0.382 which states if an increase in GDP by $1 \%$, tends to increase the elasticity of labor absorption by $0.382 \%$. Dummy variable regression coefficient (X2) of -0.575 which states that if there is an increase of $1 \%$, it will tend to reduce the elasticity of labor absorption by $0.575 \%$. The regression coefficient of the variable D Ln Q (X3) is 0.123 which states that if there is an increase of $1 \%$, it will tend to increase the elasticity of labor absorption by $0.123 \%$.

Table 4. Calculation results of $A_{0}, \alpha_{1}, \alpha_{2}$ and $t$ test on coefficients

\begin{tabular}{|c|l|r|r|r|r|r|}
\hline \multirow{2}{*}{ Model } & \multicolumn{2}{|c|}{$\begin{array}{c}\text { Unstandardized } \\
\text { Coefficients }\end{array}$} & \multicolumn{2}{c|}{$\begin{array}{c}\text { Standardized } \\
\text { Coefficients }\end{array}$} & \multirow{2}{*}{ t } & \multirow{2}{*}{ Sig. } \\
\cline { 3 - 7 } & B & Std. Error & \multicolumn{2}{|c|}{ Beta } & & \\
\hline \multirow{2}{*}{1} & (Constant) & 5.009 & 2.259 & & 2.217 & .041 \\
\cline { 2 - 7 } & GDP & .382 & .121 & .245 & 3.148 & .006 \\
\cline { 2 - 7 } & Dummy & -.575 & 2.661 & -.411 & -.216 & .832 \\
\cline { 2 - 7 } & D Ln Q & .123 & .145 & 1.581 & .853 & .406 \\
\hline
\end{tabular}

Source: Author(s) calculation

Table 4 shows that a constant value of 5.009 was obtained. GDP regression coefficient (X1) of 0.382 which states if an increase in GDP by $1 \%$ will tend to increase the elasticity of labor absorption by $0.382 \%$. Dummy variable regression coefficient (X2) of -0.575 which states that if an increase of $1 \%$ will tend to reduce the elasticity of labor absorption by $0.575 \%$. The 
regression coefficient of variable D LnQ (X3) of 0.123 which states that if an increase of $1 \%$ will tend to increase the elasticity of labor absorption by $0.123 \%$.

In proving the relationship between GDP (independent variable) and labor absorption (related variables), it is done by comparing the probability with the level of research error $(\alpha)$. If the probability is greater than the error rate $(\alpha), \mathrm{H}_{0}$ is accepted then there is no influence of the independent variable on the related variable. Conversely, if the probability is smaller than the error rate $(\alpha), H_{1}$ is accepted then there is the influence of the independent variable on the dependent variable.

Based on the analysis results in the table, the value of $t$ is 3.148 and the significance value is 0.006. Because $t$ arithmetic is greater than $t$ table that is 3.148 is greater than 2.446 and the significance value is smaller than alpha which is 0.006 smaller than 0.05 then $\mathrm{H}_{0}$ is rejected and $\mathrm{H}_{1}$ is accepted. This shows that the GDP variable influences the employment of industrial and service sectors. The results of the analysis that have been carried out are then entered into the Regression equation:

$Y=A_{0}+\alpha_{1} X_{1}+\alpha_{2} X_{2}+\alpha_{3} X_{3}$

Thus, the results of the analysis of employment absorption of the industrial and service sectors, namely:

$Y=5,009+0,382 X_{1}-0,575 X_{2}+0,123 X_{3}$

Furthermore, the equation is transformed into the Cobb Douglas formula, so that the equation is obtained:

$\mathrm{Y}=5,009+0,382 \mathrm{X}_{1}-0,575 \mathrm{X}_{2}+0,123 \mathrm{X}_{3}$

Ln $\mathrm{N}=5,009+0,382 \operatorname{Ln} \mathrm{Q}-0,575 \mathrm{D}+0,123 \mathrm{D} \operatorname{Ln} \mathrm{Q}$

Industrial Sector; $\mathrm{D}=0$

Function: $\operatorname{Ln} \mathrm{N}=5,009+0,382 \operatorname{Ln} \mathrm{Q}$

$\mathrm{N}=149,754 \mathrm{Q}^{0,382}$

Service Sector; $\mathrm{D}=1$

Function: $\operatorname{Ln} \mathrm{N}=5,009+0,382 \operatorname{Ln} \mathrm{Q}-0,575+0,123 \mathrm{Ln} \mathrm{Q}$

$\operatorname{Ln} \mathrm{N}=(5,009-0,575)+(0,382+0,123) \operatorname{Ln} \mathrm{Q}$

Ln $\mathrm{N}=4,434+0,505$ Ln Q

$\mathrm{N}=84,268 \mathrm{Q}^{0,505}$

The value of elasticity of employment in the industrial sector is $0.382<1$ which means that the elasticity of employment in the industrial sector is inelastic, while the value of the elasticity of employment in the service sector is $0.505<1$, which means that the elasticity of employment in the service sector is inelastic.

The elasticity of labor absorption illustrates how much the portion of the change in the growth of the number of workers that occurs against the portion of the change in GDP growth. To find out how much the level of elasticity of employment in the industrial sector per year follows the results of the calculation of the elasticity of employment in the industrial sector in Indonesia during 2010-2019.

Referring to Table 5, employment elasticity in the industrial sector is more in the inelastic category, only in 2 years, the category is elastic. Meanwhile, service sector employment elasticity is also more in the inelastic category, only in 2016 the category is elastic. This 
means that the GDP growth of the industrial sector and the service sector is not very encouraging in response to the growth in the number of workers in the industrial and service sectors in Indonesia.

Table 5. The elasticity of industrial absorption of labor in Indonesia, 2010-2019

\begin{tabular}{|l|c|c|c|c|c|c|}
\hline Year & $\begin{array}{c}\text { Labor } \\
\text { Sector } \\
\text { Industry } \\
\text { (People) }\end{array}$ & $\begin{array}{c}\text { Industrial } \\
\text { Sector } \\
\text { Workers } \\
(\boldsymbol{\%})\end{array}$ & $\begin{array}{c}\text { GDP } \\
\text { Sector } \\
\text { Industry } \\
\text { (IDR Million) }\end{array}$ & $\begin{array}{c}\text { Industrial } \\
\text { Sector } \\
\text { Workers } \\
(\boldsymbol{\%})\end{array}$ & $\begin{array}{c}\text { Industrial } \\
\text { Employment } \\
\text { Absorption } \\
\text { Elasticity (\%) }\end{array}$ & Category \\
\hline 2010 & $156,861,000$ & 2.41 & $80,150,778,000$ & 4.00 & 0.60 & Inelastic \\
\hline 2011 & $160,777,000$ & 2.50 & $111,428,787,000$ & 39.02 & 0.06 & Inelastic \\
\hline 2012 & $164,692,000$ & 2.44 & $83,785,454,000$ & -24.81 & -0.10 & Inelastic \\
\hline 2013 & $177,852,000$ & 7.99 & $122,581,779,000$ & 46.30 & 0.17 & Inelastic \\
\hline 2014 & $176,944,000$ & -0.51 & $123,083,781,000$ & 0.41 & -1.25 & Inelastic \\
\hline 2015 & $207,893,000$ & 17.49 & $124,253,706,000$ & 0.95 & 18.40 & Elastic \\
\hline 2016 & $210,794,000$ & 1.40 & $132,339,977,000$ & 6.51 & 0.21 & Inelastic \\
\hline 2017 & $207,667,000$ & -1.48 & $146,218,567,000$ & 10.49 & -0.14 & Inelastic \\
\hline 2018 & $190,029,000$ & -8.49 & $151,087,769,000$ & 3.33 & -2.55 & Inelastic \\
\hline 2019 & $195,298,000$ & 2.77 & $152,629,991,000$ & 1.02 & 2.72 & Elastic \\
\hline
\end{tabular}

Based on Table 6, during the period 2010-2019 the elasticity of labor absorption in the service sector was more in the inelastic category, only in 2015 and 2019 the categories were elastic. Meanwhile, service sector employment elasticity is also more in the inelastic category, specifically in 2019 the category is elastic. This means that the GDP growth of the industrial sector and the service sector is not very encouraging in response to the growth in the number of workers in the industrial and service sectors in Indonesia.

Table 6. The elasticity of service absorption of labor in Indonesia, 2010-2019

\begin{tabular}{|c|c|c|c|c|c|c|}
\hline Year & $\begin{array}{c}\text { Labor } \\
\text { Sector } \\
\text { Service } \\
\text { (People) }\end{array}$ & $\begin{array}{c}\text { Service } \\
\text { Sector } \\
\text { Workers } \\
(\boldsymbol{\%})\end{array}$ & $\begin{array}{c}\text { GDP } \\
\text { Sector } \\
\text { Service } \\
\text { (IDR Million) }\end{array}$ & $\begin{array}{c}\text { Service } \\
\text { Sector } \\
\text { Workers } \\
(\boldsymbol{\%})\end{array}$ & $\begin{array}{c}\text { Service } \\
\text { Employment } \\
\text { Absorption } \\
\text { Elasticity (\%) }\end{array}$ & Category \\
\hline 2010 & $502,791,000$ & $-0,55$ & $31,722,604,000$ & 12.83 & -0.04 & Inelastic \\
\hline 2011 & $553,721,000$ & 10.13 & $42,367,650,000$ & 33.56 & 0.30 & Inelastic \\
\hline 2012 & $604,651,000$ & 9.20 & $48,796,010,000$ & 15.17 & 0.61 & Inelastic \\
\hline 2013 & $731,747,000$ & 21.02 & $48,382,559,000$ & -0.85 & -24.81 & Inelastic \\
\hline 2014 & $797,161,000$ & 8.94 & $56,857,047,000$ & 17.52 & 0.51 & Inelastic \\
\hline 2015 & $790,250,000$ & -0.87 & $64,126,573,000$ & 12.79 & -0.07 & Inelastic \\
\hline 2016 & $816,972,000$ & 3.38 & $70,805,172,000$ & 10.41 & 0.32 & Inelastic \\
\hline 2017 & $828,416,000$ & 1.40 & $79,465,092,000$ & 12.23 & 0.11 & Inelastic \\
\hline 2018 & $778,167,000$ & -6.07 & $87,590,054,000$ & 10.22 & -0.59 & Inelastic \\
\hline 2019 & $910,305,000$ & 16.98 & $94,857,233,000$ & 8.30 & 2.05 & Elastic \\
\hline \multicolumn{7}{|c|}{ Source: Authors calculation $(2020)$} \\
\end{tabular}


The results of statistical research, it shows the elasticity value of the industrial sector of 0.382 $<1$ which states that employment in the industrial sector is inelastic with a positive number which means there is still a growth of labor absorption in the industrial sector in Indonesia in that period but the percentage growth in absorption the workforce is smaller than the percentage of economic growth.

This condition is less favorable for an economy because it can illustrate that GDP growth, especially in the industrial sector, has not yet played an effective role in increasing the activity of the industrial sector so that the use of new workers or opening new jobs in the sector is still small.

During the observation period, labor elasticity in the industrial sector was more in the inelastic category, only in 2015 and in 2019 the category was elastic. This means that the GDP growth of the industrial sector is not very encouraging in response to the growth in the number of workers in the sector.

The above conditions occur because workers in the industrial sector are replaced by production equipment in the form of modern high-tech (capital-intensive) machines. The still low quality of human resources is a problem while Indonesia has considerable natural resource potential. Modernization of the industrial sector's means of production has a direct effect on the elasticity of employment in the industrial sector.

Since 2017, the number of large and medium scale industrial companies in Indonesia has decreased, which has an impact on the decline in employment in Indonesia. Based on the results of the economic census listing in Indonesia, the industrial sector only absorbs about $10 \%$ of the total workforce in Indonesia.

In addition, high working hours in the industrial sector are associated with low wage rates and force them to increase working hours. This suggests a strategy to increase output (productivity) in the industrial sector, pursued by reducing the number of workers and increasing work hours. It seems that the shift in labor is more directed to businesses that are easily accessible, do not require the requirements of age, education, expertise, and capital so that the increase in productivity is low. Observation of data carefully and in a relatively long time, the sector whose productivity is quite significant (industrial sector) is not easily entered by workers. This can be seen from the low labor absorption elasticity. It seems that many investments that are relatively capital intensive are able to increase production and worker productivity but are not matched by high absorption.

Empirical findings are in line with what was previously investigated by Daud (2017). The growth of the primary sector and the secondary directly affect the absorption of labor, while the service sector has no effect on the absorption of labor. Then the growth of the secondary sector and the service sector directly affect the welfare of the community and indirectly affect the welfare of the people through the absorption of labor.

Based on the results of statistical research, it shows the elasticity of the industrial sector at $0.505<1$ which states that employment in the service sector is inelastic with a positive number which means there is still a growth in employment in the service sector in Indonesia during this period but\% stage of absorption growth the workforce is smaller than the percentage of economic growth. This illustrates that the service sector does not play an effective role in increasing the activity of the service sector so that the use of labor is relatively small.

Through the data presented previously (Table 1), the added value of the service sector has increased every year but in terms of employment, the service sector has increased and decreased. This can also be seen in Table 4, that the elasticity of employment absorption for 10 years in the service sector is more in the inelastic category, only in 2019 the employment absorption elasticity in the service sector is in the elastic category. This shows that the GDP 
growth of the service sector is not very encouraging in response to the growth in the number of workers in the sector.

The increase in added value in the service sector is due to an increase in the complexity of community needs so that the consumption of goods, in addition to primary needs is increasingly diverse and increasing. Similarly, the need to consume service products arising from the needs of the community. People increasingly need services that provide convenience, comfort, and satisfaction. For example in dealing with government administration, the public as customers/consumers of the government want a system that is easy and fast in completing its affairs.

The desire of the community for services that are easy and fast requires service providers to provide instantaneous services. Whereat present the service sector services are helped a lot by technological advances or are more capital intensive. This causes a shift in the level of employment in the service sector so that the elasticity of employment in the service sector is low.

The positive relationship between service industry development and employment growth has been explained (Xue et al., 2019). His study explained that the development of the e-commerce service industry in China continues to consistently absorb labor. Meanwhile, still with case studies in similar countries, Zeng \& Xia (2016) explained that the work of knowledge-intensive service industries) and the degree of urbanization have an interaction between the two.

Referring to the findings of the analysis, it shows that the elasticity of employment in the service sector is greater than the industrial sector, seen from the value of elasticity that is $0.505>0.382$. This means that the absorption of labor in the service sector is greater than the industrial sector. The elasticity of labor absorption in the service sector is greater than in the industrial sector because the service sector relies more on services so that it requires large human resources, namely labor, while in the industrial sector the labor has begun to be replaced by modern high-tech production equipment.

Investment in the field of human capital is intended to increase work productivity and therefore to increase better income in the future. Some economists agree that the human resources of a nation, not physical capital or material resources, are the factors that most determine the character and speed of social and economic development of the nation concerned.

Research by Wahyuningsih et al. (2020) also supports the empirical findings of the study, for unemployment, minimum wages had a negative and significant effect, while education had a positive and significant effect, while the Inflation Rates had a positive and not significant effect. An increase in the informal sector is needed to reduce unemployment and poverty because the informal sector is the main solution to address this problem.

More initiatives should be instigated in attracting more foreign direct investments to this country while encouraging exports activities among local entrepreneurs, to boost domestic production (Rahman et al., 2017).

\section{CONCLUSIONS}

The elasticity of employment in the industrial sector in Indonesia in 2010-2019 is positive inelastic, which means there is still a growth in employment in the industrial sector in Indonesia in that period but the percentage of employment growth is smaller than the percentage of economic growth. This means that the average economic growth during the period did not encourage the response to the growth in the number of workers. The elasticity of labor absorption in the service sector in Indonesia during the observation period is positive inelastic means that there is still a growth of labor absorption in the service sector in 
Indonesia in that period but the percentage of growth in employment is smaller than the \% of economic growth. This illustrates that the service sector does not play an effective role in increasing the activity of the service sector so that the use of labor is relatively small. Economic growth has not been consistent to be one of the factors triggering a steady increase in labor absorption from several Provinces in Indonesia. The elasticity of employment in the service sector is greater than the elasticity of employment in the industrial sector in Indonesia. The service sector is a potential sector in absorbing labor and contributing to Indonesia's GDP, besides the service sector influences and is related to other sectors.

The role of government is needed in the industrial sector and the service sector. The government needs to pay attention to the development of this economic sector by making an appropriate allocation of the number of workers and encourage increasing investor interest in investing in both sectors. The development of these two sectors has good prospects that are expected to be able to attract investors so they can open new jobs that can increase the number of employment.

The elasticity of employment in the service sector that is greater than the industrial sector illustrates that employment opportunities in the service sector have a greater influence on GDP compared to the industrial sector so that the government's role is needed to increase employment opportunities in the industrial sector by increasing more investment leading to opening new jobs is not just an investment by adding machines with advanced technology that can reduce labor.

We conducted a study based on consideration and development of what had been done previously by Habanabakize et al. (2019) concerning the relationship between employment, labor productivity, investment spending, and real wages in South Africa. However, this study emphasizes and focuses on predetermined variables.

Seeing the value of elasticity of the service sector and industry sector that is less than optimal for employment in Indonesia, studies in the future should be more varied. Hope for other researchers, especially regarding case studies in Indonesia, to be able to add time lags or involve a comparison between regions (Provinces), so that they can support long-term economic development policies. Of course, through the limitations of this study, the achievements of the economic structure of these two sectors can be seen.

\section{REFERENCES}

Ahluwalia, I. J. (1991). Productivity and Growth in Indian Manufacturing. Oxford: Oxford University Press.

Autor, D. H. \& Duggan, M. G. (2003). The Rise in Disability Rolls and the Decline in Unemployment. Quarterly Journal of Economics, 17(1), 157-205.

BPS-Statistics of Indonesia (2020). Statistical Yearbook of Indonesia 2019. Jakarta: Subdirectorate of Statistical Compilation and Publication.

Chinhui, J. \& Potter, S. (2006). Changes in Labor Force Participation in the United States. Journal of Economic Perspectives, 20(3), 27-46.

Daud, N. (2017). The Effect of Sector Economic Growth on the Performance of Employment and Welfare of People. International Journal of Business and Management, 12(9), 194-203.

Dumairy, D. (1996). Perekonomian Indonesia. Jakarta: Erlangga.

Habanabakize, T., Meyer, D. F. \& Olah, J. (2019). The impact of productivity, investment and real wages on employment absorption rate in South Africa. Social Science, 8(12), 1-15. 
Intriligator, M. D. (1980). Econometric Models, Techniques and Applications. New York: Prentice-Hall.

Jhingan, M. L. (2003). The Economics of Development and Planning. Delhi: Vrinda Publication.

Lee, M. A. \& Mather, M. (2008). U.S. Labor Force Trends. Population Bulletin, 63(2), 1-20.

Lee, Y. S. (2017). General Theory of Law and Development. Cornell International Law Review, 50(3), 432-435.

Liang, D. \& Zhang G. (2013). Determinant to the proportion of service employment: restudy on "Baumol-Fox" model. Nanjing Social Science, 8, 16-23.

Mosisa, A. \& Hipple, S. (2006). Trends in Labor Force Participation in the United States. Monthly Labor Review, 129(10), 35-57.

Porter, M. E. \& Kramer, M. R. (2019). Creating shared value. In Managing Sustainable Business. Edited by Smith, G. L. Amsterdam: Springer, 323-346.

Putri, A. I. (2012). Employment Absorption in Manufacturing Industry: Yogyakarta Case. Economic Journal of Emerging Markets, 4(2), 199-209.

Rahardjo, D. (1986). Transformasi Petani, Industrialisasi, dan Kesempatan Kerja. Jakarta: Universitas Indonesia.

Rahman, D. H., Majidi, N., Huwaina, F., Harun, N. F. \& Kasuma, J. (2017). Economic Growth in Malaysia: A Causality Study on Macroeconomics Factors. Journal of Entrepreneurship and Business, 5(2), 61-70.

Suseno, F. M. (2001). Pemikiran Karl Marx: Dari Sosialisme Utopis ke Perselisihan Revisionisme. Jakarta: Gramedia Pustaka Utama.

Wahyuningsih, D., Yunaningsih, A., Priadana, M. S., Darma, D. C. \& Purwadi, P. (2020). Why are Unemployment and Poverty Still Happening in Borneo Island, Indonesia?. International Journal of Economics and Financial Issues, 10(2), 235-241.

Xue, X. X., Wang, X. H. \& Li, L. W. (2019). Employment Absorption Capacity of E-commerce Service Industry. Journal of Coastal Research, 93, 879-882.

Zeng, S. \& Xia, J. (2016). Why rapid urbanization process cannot improve employment absorption capacity of service industry in China - also on the interactive mode innovation between service industry development with urbanization under the background of transformation and upgrading. China Finance and Economic Review, 4(9), 1-12. 